\title{
Triplodon chodo, a new species of pearly fresh water mussel from the Amazon Basin (Mollusca: Bivalvia: Unionoida: Hyriidae)
}

\author{
Maria C. D. Mansur ${ }^{1} \&$ Daniel M. Pimpão \\ ${ }^{1}$ Museu de Ciências e Tecnologia, Pontifícia Universidade Católica do Rio Grande do Sul. Avenida Ipiranga 6681, \\ Aquacultura-Malacologia, 90619-900 Porto Alegre, Rio Grande do Sul, Brasil. E-mail: maria.mansur@pucrs.br \\ 2 Coordenação de Pesquisas em Biologia Aquática, Instituto Nacional de Pesquisas da Amazônia. Caixa Postal 478, \\ 69011-970 Manaus, Amazonas, Brasil. E-mail: danielpimpao@yahoo.com.br
}

\begin{abstract}
A new species of the genus Triplodon Spix, 1827 is described based on shell samples collected on Rivers Jamari (Rondônia State) and Aripuanã (Amazonas State) from the Madeira River Basin; on the Amazon at Oriximiná and on the mouth of Tapajós River at Alter do Chão (Pará State). Triplodon chodo is a new species considered closely related to $T$. stevensi Lea, 1871, (described from the part of the River Essequibo which borders the Guianas). Triplodon chodo is distinguished from the latter by its smaller, lighter shell, the absence of a wing in the anterior region and by the delicate shape of the external sculpture, which is composed of minuscule nodules organized in rows that converge and crosses on the centre of the valves. The straight and vertical posterior margin forms a right or slightly obtuse angle with the shell's dorsal and ventral margins. The anterior region is short, low and slightly tapering, with the distal extremity situated on the half of the shell height. The dorsal and ventral margins are equally curved.
\end{abstract}

KEY WORDS. Prisodontini; South America, taxonomy.

RESUMO. Triplodon chodo, uma nova espécie de bivalve de água doce da bacia Amazônica (Mollusca: Bivalvia: Unionoida: Hyriidae). Descreve-se uma nova espécie do gênero Triplodon Spix, 1827 com base em conchas coletadas nos rios Jamari (estado de Rondônia) e Aripuanã (estado do Amazonas) da bacia do rio Madeira; no rio Amazonas, em Oriximiná e na desembocadura do rio Tapajós, junto a Alter do Chão (estado do Pará). Triplodon chodo é uma nova espécie, considerada como muito afim à $T$. stevensi Lea, 1871 (descrita para a parte do rio Essequibo que faz fronteira com as Guianas), que se distingue dessa última pela concha menor, mais frágil, pela ausência de expansão alada na região anterior e pela forma delicada da escultura externa, composta por numerosos e minúsculos nódulos organizados em fileiras que convergem e se cruzam na parte central das valvas. A margem posterior é reta e vertical formando um ângulo reto ou levemente obtuso com as margens dorsal e ventral da concha. A região anterior é curta, baixa e levemente descendente apresentando a extremidade distal situada na metade da altura total da concha. As margens ventral e dorsal são igualmente curvas.

PALAVRAS-CHAVE. América do Sul; Prisodontini; taxonomia.

The genus Triplodon Spix, 1827 is endemic to the Amazonian and Guianan hydrographic basins and is little studied due to the difficulty of access to the more central water systems of the South American continent, the lack of scientific collections of freshwater bivalves principally in the Amazon region, and to the absence of identification keys or illustrated catalogues.

HaAs (1969) cited as valid six taxa of the species group for the Amazon and Guiana: Triplodon (Triplodon) corrugatus (Lamarck, 1819), T. (Tripl.) latialatus (Sowerby, 1869), T. (Tripl.) transversus (Hupé, 1857), T. (Tripl.) rugosissimus (Sowerby, 1869), Triplodon (Triquetrana) stevensi (Lea, 1871) and T. (Triquetr.) jamauchimensis (F. Backer, 1913). Following SIMPSON (1900, 1914) in part, HAAS (1969) divided the genus into two subgenera, the first (Triplodon) distinguished by the presence of a more developed wing in the posterior dorsal region and a bigger inflation and the second (Triquetrana) by a lesser developed posterior wing and a laterally compressed shell. According to HaAs (1969), the species from the first subgenus are much more closely allied and could simply be manifesting intraspecific variation, but he maintained the species as valid based only on the figured material and on the original description because he couldn't find the type material in order to examine and revise it personally. In the second subgenus, Triquetrana Simpson, 1900, HaAs (1969) maintains $T$. (Triquetr.) stevensi separately due to the radial formation 
of the pseudocardinal teeth. All the other species described were united as synonymous with $T$. (Triquetr.) jamauchimensis due to their great overall similarity, that is, they are less wide and the sculpture has shorter bars, although they do have more lamellar teeth, similar to T. (Tripl.) corrugatus.

Recently Simone (2006) joined the genera Triplodon and Prisodon Schumacher, 1817 in only one, the genus Prisodon, considering valid only the species $P$. corrugatus and $P$. obliquus (Schumacher, 1817), keeping Paxyodon as a distinct genus inside Prisodontini. Nevertheless the genus Triplodon is herein considered as a valid according to the presence of external sculpture on the adult shell (lacking on Prisodon and Paxyodon) and on the differences of the shape and surface of the larval shells according to BonetTo \& Ezcurra (1963) and Parodiz \& BonetTo (1963). The glochidium of Prisodon obliquus is still unknown. Paxyodon and Triplodon present a larval shell with the same ventral tooth type that is similar to Diplodon, but stronger, more straight and the distal cups not so expanded. The glochidium of Paxyodon is relatively elongated and shorter ventrally (BonetTo \& Ezcurra 1963). Considering those larval differences and also the lack of morphological studies of the soft parts of the adults of Prisondontini we prefer maintain the tribe with the three above mentioned genera until more studies could demonstrate the consistency of those taxonomic categories.

\section{Triplodon chodo sp. nov.} Figs 1-6

Type material. Holotype, BrasiL, Amazonas: River Aripuanã (0600'29,6"S 60¹1'45,8”W), 13.IX.2004, D.M. Pimpão \& C. Sotero leg. (INPA 1105). Paratypes, Brasil, Pará: Oriximiná (Tabuleiro do Jacaré, River Trombetas), XII.1987, W. Zweink leg. (1 valve MNRJ 5811); Santarém (Alter do Chão, right margin of Tapajós River at Ponta do Cururu, 02 $\left.28^{\prime} 15,6^{\prime \prime} \mathrm{S} 54^{\circ} 59^{\prime} 08,0^{\prime \prime} \mathrm{W}\right)$, 14.XI.2006, D.M. Pimpão leg. (1 shell INPA 1168); Amazonas: Novo Aripuanã (River Aripuanã, between $06^{\circ} 00^{\prime} 42,3^{\prime \prime} \mathrm{S}$ $60^{\circ} 11^{\prime} 42,7^{\prime \prime} \mathrm{W}$ and $\left.06^{\circ} 00^{\prime} 21,7^{\prime \prime S} 60^{\circ} 11^{\prime} 45,1^{\prime \prime} \mathrm{W}\right), 9 . \mathrm{IX} .2004$, D.M. Pimpão \& C. Sotero leg. (2 shells INPA 330, 331a; 1 shell MCP 8863; 1 shell UFMT collection J. Parodiz 403; 1 shell MZSP 86012); River Aripuanã (between 06 $00^{\prime} 37,7^{\prime \prime} \mathrm{S} 60^{\circ} 11^{\prime} 42,8^{\prime \prime} \mathrm{W}$ and 0600'52,7"S 60¹1' 40,9"W), 12.IX.2004, D.M. Pimpão \& C. Sotero leg. (2 shells INPA 333a,b); River Aripuanã (06 00'29,6"S $60^{\circ} 11^{\prime} 45,8^{\prime \prime}$ W, 13.IX. 2004), D.M. Pimpão \& C. Sotero leg. (1 shell INPA 332; 1 shell MCP 8862); Rondônia: UHE Samuel (Rio Jamari), 15.VIII.1987, C. Motta et al. leg. (1 valve INPA 254).

Geographic distribution. Brazil, Amazon Basin, Rivers Amazonas, Madeira, Tapajós and Jamari.

Diagnosis. Shell small, light, without anterior wing, outline sub-triangular, dorsal and ventral margins equally curved, frontal distal extremity on the half of shell height, posterior margin straight and vertical, forming a right or slightly obtuse angle with the shell's dorsal and ventral margins; anterior region short, low and slightly tapering; external sculpture with narrow oblique and arched rows of minute nodules always covering the disc. Rows form ' $\mathrm{v}$ '-like figures at the centre of the valve.

\section{External view of shell}

Shell small, relatively light and short, equivalve, inequilateral, slightly inflated (Tab. I).

Shell outline roughly triangular (Figs 1 and 2); anterior region short, lacking wing or rudiments of wing, anterior and ventral margins arched in front of beaks, converging and narrowing into rounded distal extremity situated in middle of shell height. Posterior region high and winged post-dorsally; truncated vertically in smaller samples, lightly convex in bigger ones; forming a right angle both post-dorsally and post-ventrally. Dorsal and ventral margins parallel behind beaks.

Umbones low, eroded. Beaks visible only in smaller samples: small, weakly prosogyrate, scarcely prominent or slightly protruding above the dorsal margin, on first third (1/ 3) of shell's length. Ligament external, opisthodetic.

External sculpture rough having very narrow rows of minute nodules covering either the disc or the whole surface. Rows oblique and arched on anterior and posterior regions of valves, crossed and converging on disc and forming ' $\mathrm{v}$ '-like figures at centre. Behind posterior ridge rows just as rough but form arched bars orientated radially, sometimes forming chevrons on distal part of carina. Posterior ridge conspicuous, often slightly curved; upper ridge smaller and less conspicuous. Sculpture sometimes absent near anterior, ventral and posterior margins in bigger specimens. Concentric lines with slight lamellous aspect.

Periostracum dull, relatively thick, dark brownish or blackish.

\section{Internal view of shell}

Subumbonal cavity shallow, generally with two small, oval or rounded minute impressions of dorsal muscles. Internal surface smooth, silvery (Figs 3 and 4), with gentle radial undulation that stands out on subumbonal surface, behind impressions left by dorsal muscles. Impressions from adductor muscles (Figs 5 and 6) of similar sizes (both together corresponding to $5.2 \%$ of valve's surface area), with anterior impression strongly marked, more rounded and deep $(2.4 \%$ of valve area); additional small impression left by anterior retractor muscle, rounded, located under anterior pseudocardinal tooth. Pallial line conspicuous, (21.5\% of shell's height, measuring from ventral edge), parallel to posterior-ventral margins.

Hinge plate relatively strong ( $8.8 \%$ of one valve's area; width at pseudocardinals corresponding to $10.8 \%$ of shell's length) and arched. Right valve with fine, elongated anterior pseudocardinal tooth, generally low, with minute apical crenellations, separated by deep socket from relatively big, large, elongated and robust posterior pseudocardinal tooth (width $5 \%$ of shell's length) which has a distal granular surface and/or is transversally or radially or oblique striped; dorsally splitted in one or more smaller, short and rough tooth; rudiments of small, radial denticles sometimes present on region of these teeth. Lateral tooth elongated, slightly convex posteriorly dis- 

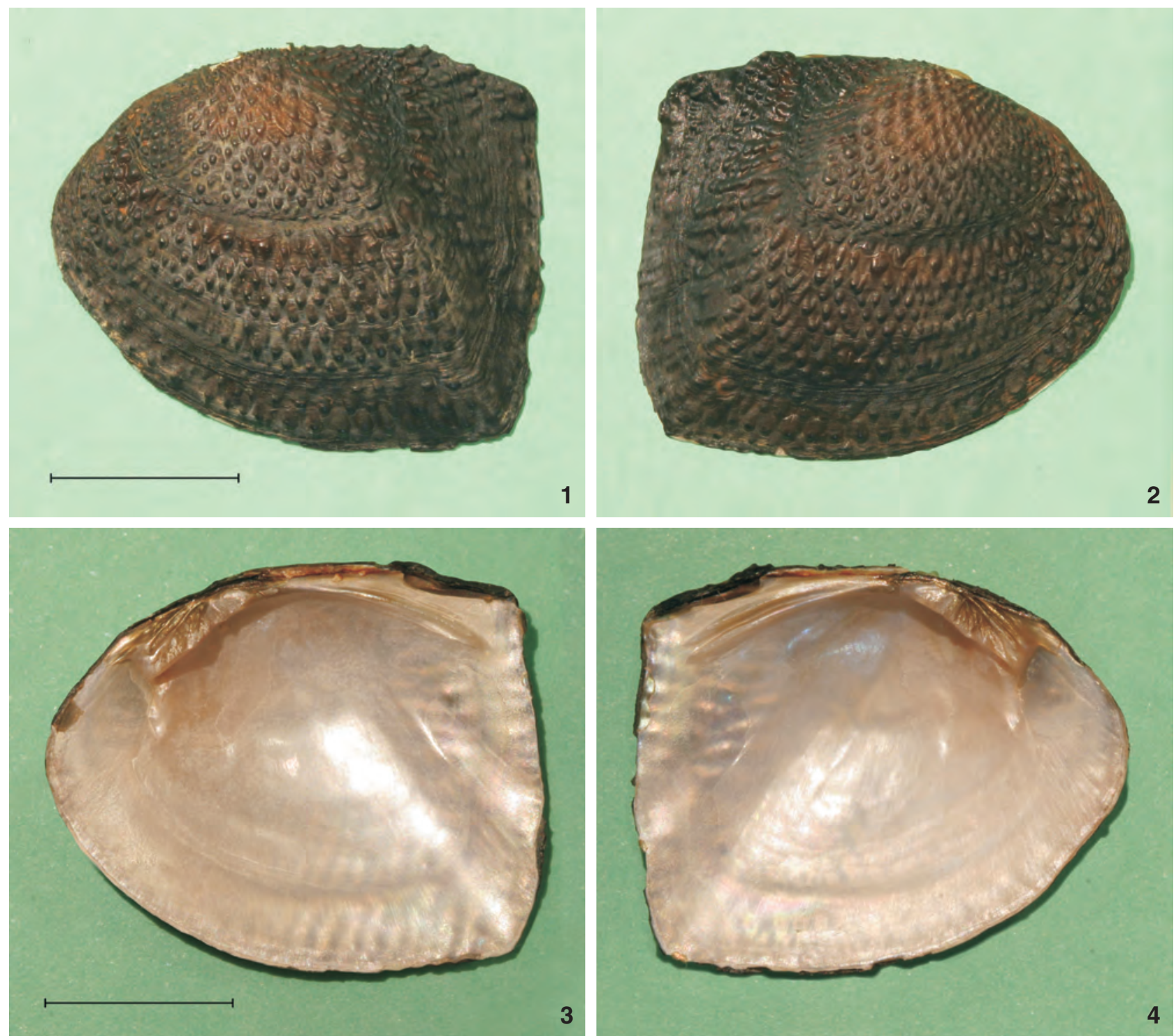

Figures 1-4. Triplodon chodo sp. nov., holotype, INPA 1105: (1-2) external view: (1) left valve; (2) right valve; (3-4) internal view: (3) right valve; (4) left valve. Bar $=1 \mathrm{~cm}$.

placed apical surface crenellated.

Pseudocardinal tooth of left valve conspicuous, narrower than corresponding one of opposite valve. It has grainy surface and is separated by socket that has rough surface from assemblage of two or more splited and short and radially or oblique oriented posterior pseudocardinal teeth, with granular or rough surfaces. Left valve with two elongated posterior lateral teeth that lie parallel to each other, slightly convex and distally smoothly crenellated. Lower lateral tooth slightly larger.

Sizes and shapes of pseudocardinal teeth variable between specimens, especially anterior pseudocardinal tooth of both valves, which sometimes is very reduced.

\section{Additional comments}

Holotype size: INPA 1105 - length $26.63 \mathrm{~mm}$, height $21.56 \mathrm{~mm}$, width $10.06 \mathrm{~mm}$.

Maximum observed size: Paratype INPA 331b - length $32.95 \mathrm{~mm}$, height $25.96 \mathrm{~mm}$, width $13.07 \mathrm{~mm}$; smaller size: paratype INPA 1168 - length $13.90 \mathrm{~mm}$, height $11.53 \mathrm{~mm}$, width 5.78. Length/height rate: 1.21 to 1.45 ; Length/width rate: 2.34 to 3.05 ; Heigth/width rate: 1.83 to 2.14 .

The valve of a young specimen of Triplodon sp., characterized by the nodes in the sculpture, very similar to this species, was illustrated by HaAs (1949: 154, fig. 2), without identification or specific description. The author mentioned that it

Revista Brasileira de Zoologia 25 (1): 111-115, March, 2008 

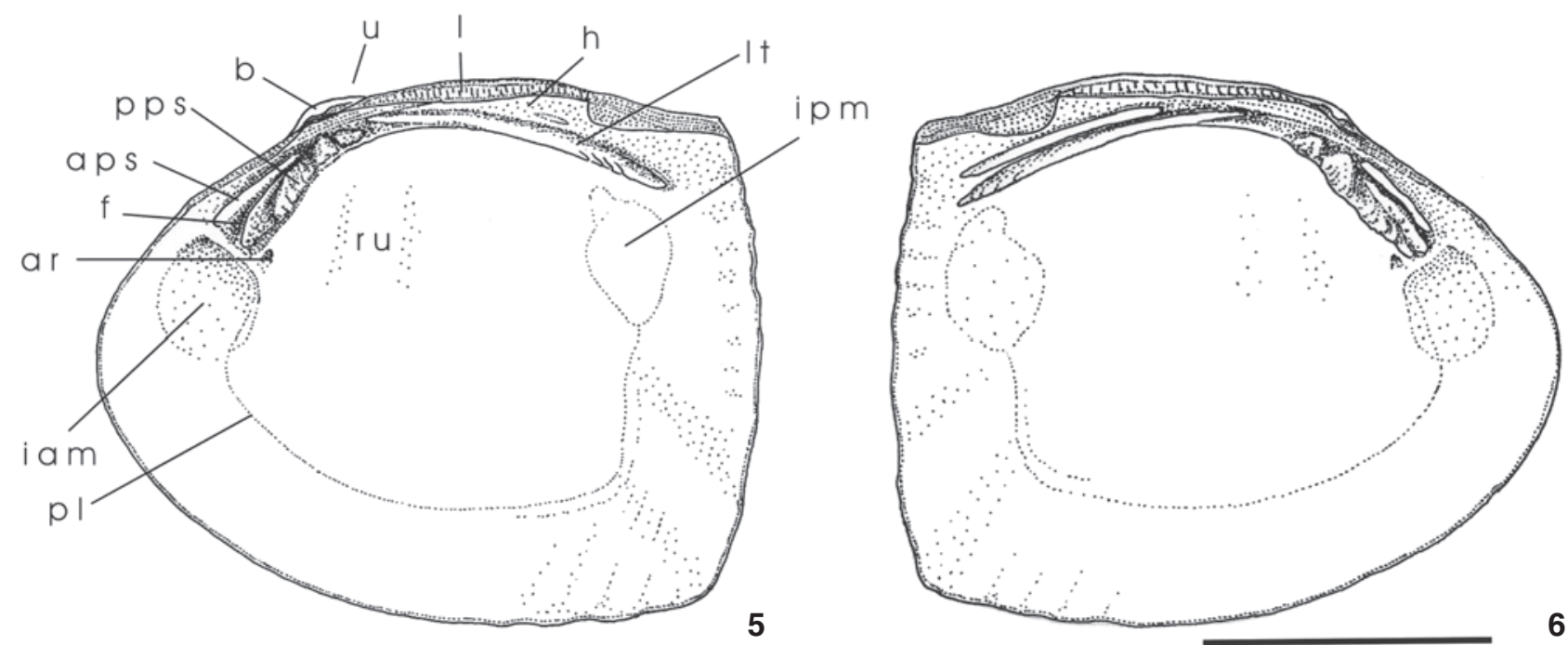

Figures 5-6. Triplodon chodo sp. nov., holotype, INPA 1105, details of the hinge: (5) right valve; (6) left valve. Bar = $1 \mathrm{~cm}$. (aps) Anterior pseudocardinal tooth, (ar) impression of the anterior retractor muscle, (b) beaks, (f) socket, (h) hinge plate, (iam) impression of the anterior adductor muscle, (ipm) impression of the posterior adductor muscle, (I) ligament, (It) lateral tooth, (pl) pallial line, (pps) posterior pseudocardinal tooth, (ru) radial undulation, (u) umbo.

Table I. Measurements of the shells of Triplodon chodo sp. nov. (INPA) Instituto Nacional de Pesquisas da Amazônia; (MCP) Museu de Ciências e Tecnologia da Pontifícia Universidade Católica do Rio Grande do Sul; (MNRJ) Museu Nacional do Rio de Janeiro; (JPMT) Coleção de Moluscos Juan Jose Parodiz, Universidade Federal do Mato Grosso; (MZSP) Museu de Zoologia da Universidade de São Paulo.

\begin{tabular}{|c|c|c|c|c|}
\hline Collection numbers & Type material & Lenght (mm) & Height (mm) & Width $(\mathrm{mm})$ \\
\hline INPA 1105 & Holotype & 26.63 & 21.56 & 10.06 \\
\hline INPA 331b & Paratype & 32.95 & 25.96 & 13.07 \\
\hline INPA 333a & Paratype & 29.60 & 21.78 & 11.91 \\
\hline INPA 254 & Paratype & 29.56 & 20.45 & 4.84 * \\
\hline INPA 332a & Paratype & 29.25 & 22.61 & 11.06 \\
\hline MCP 8863 & Paratype & 27.60 & 22.40 & 11.77 \\
\hline MZSP 86012 & Paratype & 24.66 & 19.20 & 9.42 \\
\hline MCP 8862 & Paratype & 23.90 & 19.18 & 9.57 \\
\hline INPA 330 & Paratype & 22.50 & 18.64 & 9.49 \\
\hline JPMT 403 & Paratype & 22.09 & 18.09 & 9.18 \\
\hline MNRJ 5811 & Paratype & 21.66 & 17.00 & 8.64 \\
\hline INPA 333b & Paratype & 16.75 & 12.95 & 6.29 \\
\hline INPA 1168 & Paratype & 13.90 & 11.53 & 5.78 \\
\hline
\end{tabular}

* Measurements of one valve.

was probably a new species. He didn't dare describe it due to the small amount of material of whatever it might have been. The valve was less than $1 \mathrm{~cm}$ long, collected on the forest floor in the locality of Belterra, in the vicinity of the Rio Tapajós. In the collection of the Museu Nacional a complete shell was found from Oriximiná, Rio Trombetas and, in the INPA Mollusc Collection (INPA 254), a second specimen was found comprising the left valve, with the postero-dorsal region lightly damaged, with the same characteristics as the specimen from the Museu
Nacional and the material in HAAs's (1949) figure.

The known distribution of the species (Fig. 7) is so far restricted to the Amazon Basin, specially on the Madeira River and from the point where it enters the Amazon to the mouth of Tapajós River. At extreme points, as at the Rivers Jamari (Rondônia) and Tapajós (Pará), the specimens show a more nodulous sculpture over the whole of the external surface. In the intermediate area where the Aripuanã tributary is situated, specimens present a finer sculpture which does not always cover 


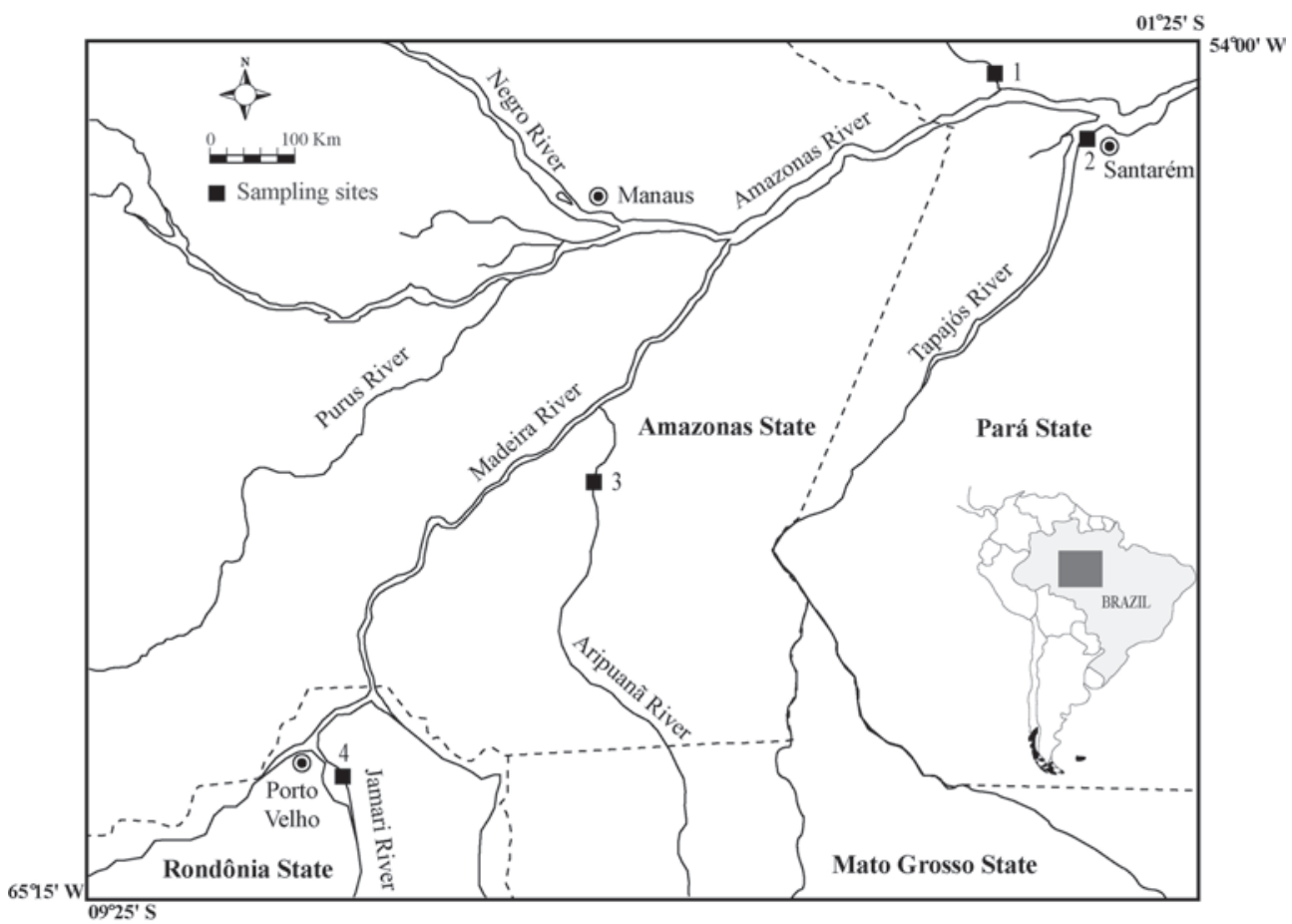

Figure 7. Map showing the known geographical distribution of Triplodon chodo sp. nov. and the sampling points on Central Amazonian Basin. Simbols: $(\square)$ sampling points, $(\odot)$ cities or capitals of the states, (---) political divisions of Brazilian states of Pará, Amazonas, Mato Grosso and Rondônia.

the whole external surface. Apart from the variability in the extent of the area of sculpture, all of the mussel's characteristics remained consistent in the material examined. It is true especially for the shape of the shell's curve and the delicate and nodulous nature of the sculpture.

Etymology. In colloquial Brazilian Portuguese the species name means something precious and adorable, and is suggested in recognition of the senior author's three grandchildren: Eric, Daniel and Isadora.

\section{ACKNOWLEDGEMENTS}

To Norma Salgado, curator of the Museu Nacional Rio de Janeiro (National Museum of Rio de Janeiro), for the loan of material; Célio Magalhães, Instituto Nacional de Pesquisas da Amazônia, for the invitation to work on the Invertebrate Collection, and to CNPq for fundings (Visiting Researcher grant numbers PCI/MCT/INPA and DCR). FAPEMAT/CNPq for the grant DCR to the senior author 35.0205/2004-3 NV, and funding FAPEMAT 4.2.12.52/02-2004 E.. To CNPq for the grant to the junior author - Program PCI (MCT-INPA/CNPq 38.0193/ 2004-3) and doctor scholarship. To Projeto Probio (MMA/CNPq/ GEF/PNUD/World Bank) that permited the field work on the Rivers Madeira and Aripuanã; and Programa de Capacitação em Taxonomia (MCT/CNPq/CAPES) that permitted the field work on the River Tapajós. To Claudio D. de Araujo for photograph- ing and editing images. To Vanessa Gazulha and Daniel Pereira for editing respectively the map and the schematic design.

\section{LITERATURE CITED}

BonetTo, A.A. \& I.D. Ezcurra. 1963. Notas Malacologicas 1-2. El Golchidium de Prisodon (Triplodon) corrugatus Lam. Physis 24 (67):17-21.

HAAs, F. 1949. Land and Süsswassermollusken aus dem Amazonas-Gebiete. Archiv für Molluskenkunde 78 (4-6): 149-156.

HaAs, F. 1969. Superfamilia Unionacea. In: R. Mertens; W. Hennig \& Wermuth (Eds). Das Tierreich. Berlim, Walter de Gruyter, vol. $88, \mathrm{I}-\mathrm{X}+663 \mathrm{p}$.

Parodiz, J.J. \& A.A. BonetTo. 1963. Taxonomy and zoogeographic relationships of South American naiades (Pelecypoda: Unionacea and Mutelacea). Malacologia 1 (2): 179-213.

SimONe, L.R.L. 2006. Land and freshwater molluscs of Brazil. São Paulo, EGB, FAPESP, 390p.

Simpson, C.T. 1900. Synopsis of the Najades or pearly fresh-water mussels. Proceedings of the United States National Museum 22 (1205): 501-1044.

SIMPSON, C.T. 1914. A descriptive catalogue of Naiads, or pearly fresh-water mussels. Part 1, Unionidae. Detroit, Bryant Walker, p. 1195-1470.

Received in 01.III.2007; accepted in 24.II.2008. 